\title{
French Fathers in Work Organizations: Navigating Work-Life Balance Challenges
}

\author{
Sabrina Tanquerel
}

\section{Introduction}

In France, like many other developed countries, men increasingly seek a better worklife balance in order to spend more time at home, especially when fathers of young children (ORSE 2010, 2014; Gregory and Milner 2012; UNAF 2016). Studies about "new fathers" and "l'homme nouveau" ["the new man"] (Castelain-Meunier 2013) question whether France is heading to changing norms of masculinity. According to a national survey (OPE 2017), 64\% of French fathers declare they do not have enough time to do what they wish with their children. Fathers also report that their employers do not help them combine their work and family life (69\%). Fathers would like them to train supervisors to make them more aware of their teams' personal life, and more generally take into account their role as fathers. These new expectations are also visible in the increased paternal leave usage in France (14 days): $70 \%$ of French fathers benefit from it, an increase of $20 \%$ since its creation in 2002 (DREES 2016).

Nevertheless, fathers struggle between the desire to be involved fathers (spending time and engaging with their children during the working week) and their role as the main breadwinner in the family (facing and managing the demands of "greedy" organizational cultures [Kvande 2012]). Time use surveys show that men still spend more time at work and less time in childcare than women (Insee 2010), which suggests that the discourses of fathers on fatherhood may differ from their practices (LaRossa 1988; Dermott 2008; Hunter et al. 2017). Caught between traditional and modernized conceptions of fatherhood, they cope with ambivalence, tensions, and asynchronicities in the workplace (Liebig and Oechsle 2017).

\footnotetext{
S. Tanquerel (凶)

Ecole de Management de Normandie, Campus de Caen, France

e-mail: stanquerel@em-normandie.fr 
France provides a particularly relevant and rich context for the analysis of fatherhood in organizations. Indeed, though France has a specific family policy based on natalism with a generous childcare system, it also has a 'hypermaternalised' policy tradition, historically oriented towards mothers. The country maintains a strong male breadwinner culture, which may explain the underdevelopment of its fatherhood regime. However, as is happening in many developed countries, there is evidence of attitudinal change by fathers and organizations. The tensions triggered by this change are part of a long-term process of "lagged adaptation," a state of transition worthy of interest for many states and organizations.

Yet, little research is focused on fatherhood in work organizations in France. This chapter addresses this issue by focusing on deeply embedded and change-resistant gendered workplace practices and cultures that can undermine active fatherhood. More specifically, this chapter answers the questions: (1) What are the challenges/ tensions between the simultaneous pressure of having a successful career and of embodying an involved fatherhood that French working fathers experience? (2) What practices and strategies do fathers leverage to face these challenges in the organizational context? The aim is to stimulate reflection regarding how to create and contribute to systemic change in workplaces (Lewis and Stumbitz 2017).

Based on 20 interviews conducted in France with fathers from heterogeneous backgrounds working in family-friendly companies, I present findings regarding their "talk" on work-life balance (WLB). I will first outline my theoretical approach and the state of current research, as well as the methods and data. I will then present empirical insights about their individual experiences of WLB. In the last section, based on the results, I will discuss the different ways fathers decide to combine work, non-work, fathering, and how different factors such as their professional ideals and self-concepts of fatherhood influence their degree of involvement. Finally, I will end with some further recommendations regarding how organizations can foster a truly father-friendly environment.

\section{Men's New Aspirations: Juggling Traditional Male Identity and Organizational Constraints}

Unlike women, men's difficulties managing work-life tensions have been understudied. Women's adaptations to work have been thoroughly examined and explained in light of their relation to work-family reconciliation and the difficulties they experience when challenging professional expectations (e.g., Blair-Loy 2003; Budig and England 2001; Hochschild and Machung 1989; Pocock 2005; Wood and Newton 2006). But men's uninterrupted full-time work model, exclusive of other life domains, has long been taken for granted. Although a plurality of masculinity models and practices are operating in the workplace (Carrigan et al. 1985; Collinson and Hearn 1994; Connell and Messerschmidt 2005), numerous studies reveal that men and masculinity still correlate strongly to gainful employment and occupational 
career. Men have few other ways to define their identity than by the (paid) work they do (Yancey Martin 2001). Yet, researchers have questioned the notion of working life as the main arena for constructing male identity and mastery — and particularly the aspiration for career success (Connell 1995; Collinson and Hearn 2005). In Europe, the traditional patterns of the workplace, being the primary requirement that structures men's time, persist (e.g., Blossfeld et al. 2006). As men often hold the most powerful positions, the pressure to work long hours (Kvande 2009) still exist, and workplaces are still 'greedy' (Coser 1974; Kvande 2012) for time use.

Recent research has problematized men's role as fathers with the request for a new father's role (Brandth and Kvande 2002; Kimmel 2004; Kugelberg 2006; Marsh and Musson 2008). Men have new aspirations, yearning to become more involved at home (Dermott 2008; Kaufman 2013), and the demands of work organizations sharply contrast with fathers' intentions of making working life adapt to family life (Brandth and Kvande 2002). Work organizations are rarely gender neutral and have a rather 'traditional' gender perspective of the couple, with women as primary caregivers, men as work-primary and breadwinners (Ladge and Greenberg 2019). Companies handle and interpret fathers' and mothers' parental claims differently. Research suggests that men experience a greater degree of bias compared to women when they take advantage of family friendly policies at work (Cain Miller 2014; see also Ladge and Humberd and Harrington in this volume). Companies frame fathers' parental leave as a luxurious addition to support mothers (Haas and Hwang 2019), who remain in the gender-specific position of the primary parent responsible for childcare (Neumann and Meuser 2017).

In addition, research indicates the existence of strong barriers to men taking up WLB measures (Tanquerel and Grau-Grau 2020). Due to strong dominant norms of masculinity constructed as breadwinner not as carer, men who take parental leave may suffer from stigmas ('poor worker' and 'femininity' stigmas; see Coltrane et al. 2013). As research increasingly reports the difficulties men experience when facing highly challenging employer expectations (Galinsky et al. 2009; Harrington et al. 2011), aspirations toward involved fatherhood (Harrington et al. 2011; Kaufman 2013) seem to be incompatible with the pattern of hegemonic masculinity (Murgia and Poggio 2013). When men dissociate themselves from the traditional masculine norm of being devoted to and continuing full-time work, they digress from the dominant gender order and challenge the norms of the work sphere. They question the prevalent expectation that men do not have any duties besides gainful employment. Even when fathers are granted rights, they still can encounter resistance to taking advantage of these rights within their company (Brandth and Kvande 2002; Liebig and Oechsle 2017). Reductions in working hours are still often interpreted as a lack of professional commitment. Fathers who request or take parental leave may still be considered by their employers to be less ideal workers than other men. Taking family leave can also be seen as an infringement of man's masculinity (Doucet and Merla 2007). The lack of alternative models to these traditional norms of masculinity and fatherhood, even if they are eroding, remains also a strong barrier to men's taking up of WLB initiatives. 
In this ambivalent context of imposed masculinities and men's new aspirations, little research in France has considered fathers individual experiences and interpretations of work-life balance in the workplace and how they deal with these tensions. Research is abundant in demography (Brugeilles and Sebille 2009a, b, 2011, 2013) and sociology (Castelain-Meunier 2005, 2013; Le Talec 2016; Martial 2016) but are limited to describing sociological behaviors. However, little research in organization studies has considered how those tensions impact male employees in the workplace and which strategies fathers use to face those challenges. The goal of this study is therefore to understand how French men navigate their needs for flexibility to better balance their work and non-work responsibilities, within the normative (and hidden) rules that the organization implicitly imposes. It aims at highlighting men's subjective experiences, visions, practices of flexibility in challenging organizations.

\section{Fatherhood in the French Social Context}

France provides a particularly interesting case for the analysis of fatherhood in organizations because of its national family policy based on natalism with a generous childcare system, but an underdeveloped fatherhood regime (Gregory and Milner 2008).

\subsection{A Natalism-Based and Mother-Centered Family Policy}

France has a distinct family policy, based on significant support for childbirth or natalism, with generous family benefits for households with children and explicit support for larger families (Levy 2005; see also Fig. 1 below).

$\Rightarrow$ Highly developed childcare system funded on average $80 \%$ by the State:

- Daycare centers ("crèches"): where a child can be placed from the age of $2 \frac{1}{2}$ months to 3 years).

- Registered childminders ("assistante maternelle"): regulated and certified by the State, regularly inspected and trained, they are the main type of out-of-home childcare in France representing $69 \%$ of the total available places for children under 3 (DREES 2018).

- Public preschool: though the official age for school entry in France is 6 years, $97 \%$ of children aged 3 and $99 \%$ aged 4 attend preschool ("école maternelle") which is free of charge (Gomajee et al. 2017).

$\Rightarrow$ Family benefits for households with children and large families.

$\Rightarrow$ This external support can explain in part the country's relatively high fertility rate: at 2.01 child per family, France had the second-highest fertility rate in the EU, behind Ireland (Moss 2013; SPSS 2013).

Fig. 1 France: a pro-natalism country 
Nonetheless, France has had a mother-centered family policy, historically aimed at supporting working mothers with childcare provision, and which is widely held to entrench traditional gender roles. This context of a traditional 'hyper-maternalisation' of family policy (for 'hyper-maternalisation': see Castelain-Meunier 2005) has constituted a powerful constraint on the development of 'fatherhood policies' and the emergence of a strong fatherhood regime.

\subsection{The Fatherhood Regime in France}

Today, paternity leave in France consists of three "birth" days (available to all fathers on the birth of a child) added to eleven days' leave, none compulsory. 70\% of French fathers benefit from it. In order to access the leave, fathers must notify their employer a month in advance, and they are entitled to a wage-related benefit funded by the health insurance scheme and administered by the family benefits agency. In addition to this advantage, fathers have also the possibility to take a long parental leave, conditions of access to which have been evolving in the last decades as detailed in Table 1.

The 2014 law aims to increase men's take-up of post-childbirth parental leave to $25 \%$ of eligible fathers from the take-up rate of $5 \%$ today. The main obstacle for men's usage of parental leave remains a low compensation payment, which makes the benefit only minimally incentivizing for them.

Table 1 Parental Leave in France

\begin{tabular}{|c|c|c|c|}
\hline Family benefits & Introduction & Beneficiaries & Duration of the benefit \\
\hline $\begin{array}{l}\text { APE Allocation Parentale } \\
\text { d'Éducation (parental edu- } \\
\text { cation benefit) }\end{array}$ & 1986 & $\begin{array}{l}\text { - Parents of } \\
\text { children under } 3 \\
-\quad \text { Initially } \\
\text { available from } \\
\text { the third child } \\
\text { only }\end{array}$ & - 1 year, renewable twice \\
\hline APE & 1994 & $\begin{array}{l}\text { - Parents of } \\
\text { two children }\end{array}$ & - 1 year, renewable twice \\
\hline APE & 2004 & $\begin{array}{l}\quad-\text { Parents } \\
\text { from the first } \\
\text { child }\end{array}$ & $\begin{array}{l}-6 \text { months, renewable } \\
\text { once }\end{array}$ \\
\hline $\begin{array}{l}\text { PreParE } \\
\text { Prestation Partagée } \\
\text { d'Education de l'Enfant } \\
\text { (shared benefit for child's } \\
\text { education) }\end{array}$ & 2014 & $\begin{array}{l}- \text { Parents } \\
\text { from the first } \\
\text { child }\end{array}$ & $\begin{array}{l}\text { - Extended to } 1 \text { year if half } \\
\text { of the existing parental leave is } \\
\text { reserved for the second parent, } \\
\text { on a 'use it or lose it basis' } \\
- \text { Longer leave entitlement } \\
\text { of two and a half years still } \\
\text { applies to mothers expecting a } \\
\text { second or third child, whilst } \\
\text { fathers are entitled to } 6 \text { months }\end{array}$ \\
\hline
\end{tabular}




\subsection{Difficult Articulation Between Fatherhood and Work}

In the French case, even if the paternity leave of around 2 weeks has now become an accepted norm for male employees, particularly those working in larger firms (Gregory and Milner 2011; Milner and Gregory 2015), fathers still report difficulties in their articulation between fatherhood and work. The constant rate of take-up also indicates some difficulties for around a third of employees. Whilst paternity leave has become the norm for lower-paid employees, it is less widely used by highergrade employees. This may be because these higher-paid employees are able to access flexible working without having to face the income ceiling of statutory paternity pay. It is also thought to reflect the culture of "presenteeism" (on which, see Gatrell 2011) which is thought to be affecting increasing numbers of managerial employees, of whom approximately 60\% are men (Pak and Zilberman 2013; SPSS 2013), although reliable data are scarce precisely because it is a 'hidden phenomenon' which does not appear in working time statistics. This explains in part the low rate of usage of work-family policies among men and that no change occurs to fathers' working patterns as the result of their becoming parents. Unlike mothers, fathers rarely change their working schedule after child's birth and continue to work full-time (Pailhe and Solaz 2009).

The usage of WLB policies by men comes from a complex dynamic between national fatherhood regimes, organizational and sector characteristics, and the individual employee (Gregory and Milner 2011). That is why this paper aims to analyze how working fathers navigate the main challenges and tensions in trying to achieve WLB and which practices and strategies they leverage in the organizational context.

\section{Methods and Data}

This exploratory study is based on 20 semi-structured interviews of French working fathers from heterogeneous backgrounds selected in order to grasp a wide range of fathers' experiences: blue-collar (operators, technicians) and white-collar fathers (engineers, directors). The 11 companies where they work are certified as familyfriendly employers. They are both public and private, of different sizes and sectors (delivery service sector, microelectronics, automotive, IT ...) and located in Normandy (France). All interviews were conducted face-to-face from 2014 to 2017. Each interview took about $1 \mathrm{~h}$ and was conducted in French. Each interview was based on a talk about WLB and fatherhood, perceptions of WLB initiatives, reasons for use, obstacles and facilitators, and strategies. Interviews were audio-recorded and transcribed.

The interview analysis consisted of an axial coding and a thematic analysis, both horizontal and vertical. The aim was to understand and to compare fathers' representations, experiences, and behaviors regarding WLB. The data analysis consisted of two steps: firstly, examining the individual unit of production of each interview, in 
Table 2 Interviewees' characteristics

\begin{tabular}{l|l|l|l|l|l}
\hline & Name & Age & Occupation & Marital Status & Working time \\
\hline 1. & Matthias & 28 & Operator & $\begin{array}{l}\text { Perm. Relation- } \\
\text { ship, 1 child }\end{array}$ & $\begin{array}{l}\text { Full-time - staggered working } \\
\text { hours 4 days a week }\end{array}$ \\
\hline 2. & Noël & 35 & $\begin{array}{l}\text { Expert } \\
\text { operator }\end{array}$ & $\begin{array}{l}\text { Perm. Relation- } \\
\text { ship, 2 children }\end{array}$ & Full-time 4 days a week \\
\hline 3. & Pierre & 48 & Operator & Married, 2 children & Full-time \\
\hline 4. & Simon & 22 & Operator & Single, 1 child & Full-time 4 days a week \\
\hline 5. & Stéphane & 44 & Operator & Married, 3 children & Full-time (has been on part-time) \\
\hline 6. & Tony & 40 & $\begin{array}{l}\text { Expert } \\
\text { operator }\end{array}$ & $\begin{array}{l}\text { Blended family, } \\
\text { 6 children }\end{array}$ & Full-time 4 days a week \\
\hline 7. & Bertrand & 51 & $\begin{array}{l}\text { Sales } \\
\text { assistant }\end{array}$ & Married, 2 children & Full-time \\
\hline 8. & Yvan & 27 & Operator & $\begin{array}{l}\text { Perm. Relation- } \\
\text { ship, 2 children }\end{array}$ & Full-time \\
\hline 9. & Francis & 47 & Team leader & $\begin{array}{l}\text { Divorced, } \\
\text { 2 children }\end{array}$ & Full-time \\
\hline 10. & Louis & 37 & Team leader & Married, 1 child & Full-time \\
\hline 11. & Olivier & 47 & IT technician & Married, 2 children & Part-time 80\% \\
\hline 12. & $\begin{array}{l}\text { Jean- } \\
\text { Baptiste }\end{array}$ & 43 & Librarian & Married, 2 children & Part-time 80\% \\
\hline 13. & David & 41 & Engineer & $\begin{array}{l}\text { Perm. Relation- } \\
\text { ship, 1 child }\end{array}$ & Full-time \\
\hline 14. & Frédéric & 42 & Engineer & Married, 2 children & Full-time (1 day teleworking) \\
\hline 15. & Yoann & 30 & $\begin{array}{l}\text { Marketing } \\
\text { analyst }\end{array}$ & Married, 1 child & Full-time \\
\hline 16. & Romuald & 51 & Director & Married, 2 children & Full-time \\
\hline 17. & Xavier & 46 & Engineer & Married, 2 children & Full-time (1 day teleworking) \\
\hline 18. & Sébastien & 38 & $\begin{array}{l}\text { Sales } \\
\text { representative }\end{array}$ & Married, 2 children & Full-time \\
\hline 20. & Jérémy & 32 & Electrician & Married, 2 children & Full-time \\
\hline & & & & & \\
\hline
\end{tabular}

order to create categories and analyze themes, and secondly, extracting meaning from the data to understand the contents. We did an iterative coding of recurring first-order categories ("informant's voice") and identified both emerging secondorder categories and aggregate dimensions (Gioia et al. 2013) that brought to light the main dimensions of fathers' beliefs, experiences, and strategies regarding WLB policies. All names are pseudonyms. See Table 2 for details. 


\section{Empirical Findings}

\subsection{Fathers' Talk on WLB: Combining Needs, Professional Challenges and Changing Social Expectations}

\subsubsection{Masculine Meanings of WLB for Differentiated Needs}

Our research brings into focus the masculine meanings of WLB policies. Most of the men associate WLB with occasional and informal arrangements. In our interviews, men do not really ask their supervisor for time flexibility or long-term changes to their working schedules to adapt their children' needs. They rather reported occasional requests (WLB as an 'emergency').

"If one day, someone has a problem and tells us that he/she has to change his/her working schedule and/or leave earlier, we will say $O K$ and be ready to help, insofar as possible, we will try. As an example, we now have an employee whose wife is training in Paris for two days. He usually starts work at 6:00 but he asked us to start later on these days to look after his three children. We cannot allow ourselves to refuse something like this..." [Louis, 37 , team leader; married, father of 1 ].

When referring to WLB, they often mention the social benefits (financial, material, banking facilities) provided by the company. They evaluate WLB initiatives in quantitative terms since social benefits contribute to family well-being.

"From a financial perspective, these initiatives are interesting for everybody. All these initiatives and help provide well-being for everybody, for the person who is working of course but also for his/her family, because the whole family can take advantage of all the benefits that we have for sport. It is the same for bonuses, the whole family will enjoy them" [Pierre, 48, operator; married, father of 2].

\subsubsection{Professional Ideals and the Role the Organization Should Play in WLB}

The fathers interviewed generally see fatherhood as a "private matter" in the workplace. Some fathers do not necessarily view the organization as a source of solutions for a better WLB, as illustrated by Francis's discourse:

\footnotetext{
"Before working with this new director that we have now, it was you have to sort it out by yourself!' In the past, whether you started at 5:30 or 6:00 am, nobody cared, nobody wanted to hear about it. You have children, it is your choice, and you have to manage it. The company is not responsible for your personal choice." [Francis, 47, team leader; divorced, father of 2].
}

For many of them, especially those in higher positions, work continues to determine primarily time use, highlighting a powerful work-devotion schema. Fathers added that they believe they have flexibility in their time schedule since they are managers, but they also recognize that this flexibility is a double-edged facility since it is difficult to put limits. 
"When you are a manager, you have to adapt your life to your work. . you have to adapt to the employees and the company, not the opposite! Managing people takes time and sometimes it is difficult to put limits." [Louis, 37, team leader; married, father of 1].

Not everyone agrees with the role the organization has to play in WLB facilitation. Some reject the intrusion of the employer in their personal life. Others consider that communication and dialogue with supervisors is a mainstay for harmonizing both spheres. The fathers in lower professional positions seem to make their needs more visible than the fathers in higher status who do not express visible expectations.

"The lack of dialogue might be an obstacle for WLB. I think that here we have a lot of dialogue, which entails that for example, our director relatively knows about our personal lives, not everything of course, but she knows what happens. Therefore, yes, because of that, she always has an adapted response to our problems and difficulties. Compared to 4 or 5 years ago, we all had taken different ways, and she has always known how to respond to our problems, and this has improved considerably our quality of work, and by the way, our lives... " [Matthias, 28, operator; permanent relationship, father of 1].

\subsubsection{Self-Concepts of Fatherhood}

The way men conceive fatherhood determines the degree of the father's involvement and influence the needs for WLB. In some cases, fathers decide to make their needs visible to the company and to ask for part-time adjustments.

"I have already worked part-time to take care of my three daughters. I could pick up my little daughter in the afternoon, she is 10 months and I looked after her and afterwards, I took care of my other 2 daughters, they are older, when they came back from school, I prepared the snack and then did some house chores..." [Stéphane, 44, operator; married, father of 3].

We also observe that fathers negotiate their domestic role with partners, in particular when their partner works. Men's breadwinner role is shaped by their own gender role attitudes and aspirations as well as by their partners' expectations and constraints.

"Anyway, today, mothers and fathers have to work, if there are not two salaries, life is very complicated. Therefore, I think that men have to participate more in family and domestic life. My wife is passionate about her work and does not have as much as flexibility as me, that's why I adjust my schedule to hers and take advantage of the work-family initiatives that are available in my company." [Tony, 40, expert operator; blended family, father of 6].

\subsection{Fathers' 'walk' on WLB: Three Ways of Combining WLB and Fatherhood}

One of the research questions of this chapter was to explore the strategies French fathers leverage in the workplace to manage their work and family interface. The results of this study highlight three main categories of fathers using diverse strategies to navigate WLB challenges, echoing research of typologies that categorize fathers 
in their attitudes and behaviors (old dads, new dads, and superdads (Kaufman 2013); traditional, transitionals, and superdads (Cooper 2000)).

\subsubsection{The Breadwinner Father}

The underlying cultural ideal in this first category is the traditional breadwinner model, the classic ideal of fatherhood. A father should be first a "good worker." Professional identity/role is salient to the other life roles. Even if the organizational environment is family-friendly and working-time regime favorable, the workdevotion schema is dominant. These fathers do not use formal family-friendly programs. Family and fatherhood are considered a "private matter." This model reproduces the gender order and reinforces hegemonic masculinity.

"Asking for flexibility arrangements is not really compatible with a career, and by principle, I consider that we do not have children to take advantage of it. . ." [Romuald, 51, Director; married, father of 2].

\subsubsection{The Caring Father}

The underlying cultural model is the involved father. A "good father" is the one who wants to be involved at home. The desire to spend time and engage with children during the working week is important and prevails on career and professional priorities. These fathers use formal family-friendly programs, thinking that responsibility for achieving WLB is not assigned to women. Flexibility is visible because they desire it or because they have no choice (partner's position). They "challenge" the gender order and resist hegemonic masculinity, building caring masculinities (Elliott 2016). They are egalitarian in their opinions, attitudes and acts.

"Today, I work at 80\%... (When we had our second child), I really felt like spending time with my children and the idea of a day off a week to take care of them tempted me. It was really me who was calling for more qualitative time with my kids and it was naturally that I took this decision." [Jean-Baptiste, 43, librarian; married, father of 2].

\subsubsection{The 'want to have it all' Father}

The cultural model is hybrid: 'career oriented' and 'caring father'. He wants to be both: a good worker and a good father. He is aware of the "hidden rules" in organizations. The desire to balance different life areas is dependent on career. The ideal worker norm is accepted and internalized. They are egalitarian in their discourse but not necessarily in their acts. The will to emancipate from the gender order is present. They may use family-friendly policies but prefer informal arrangements since flexibility is seen as a risk to career. They "conform" to the gender order and maintain a type of complicit masculinity (Fig. 2). 


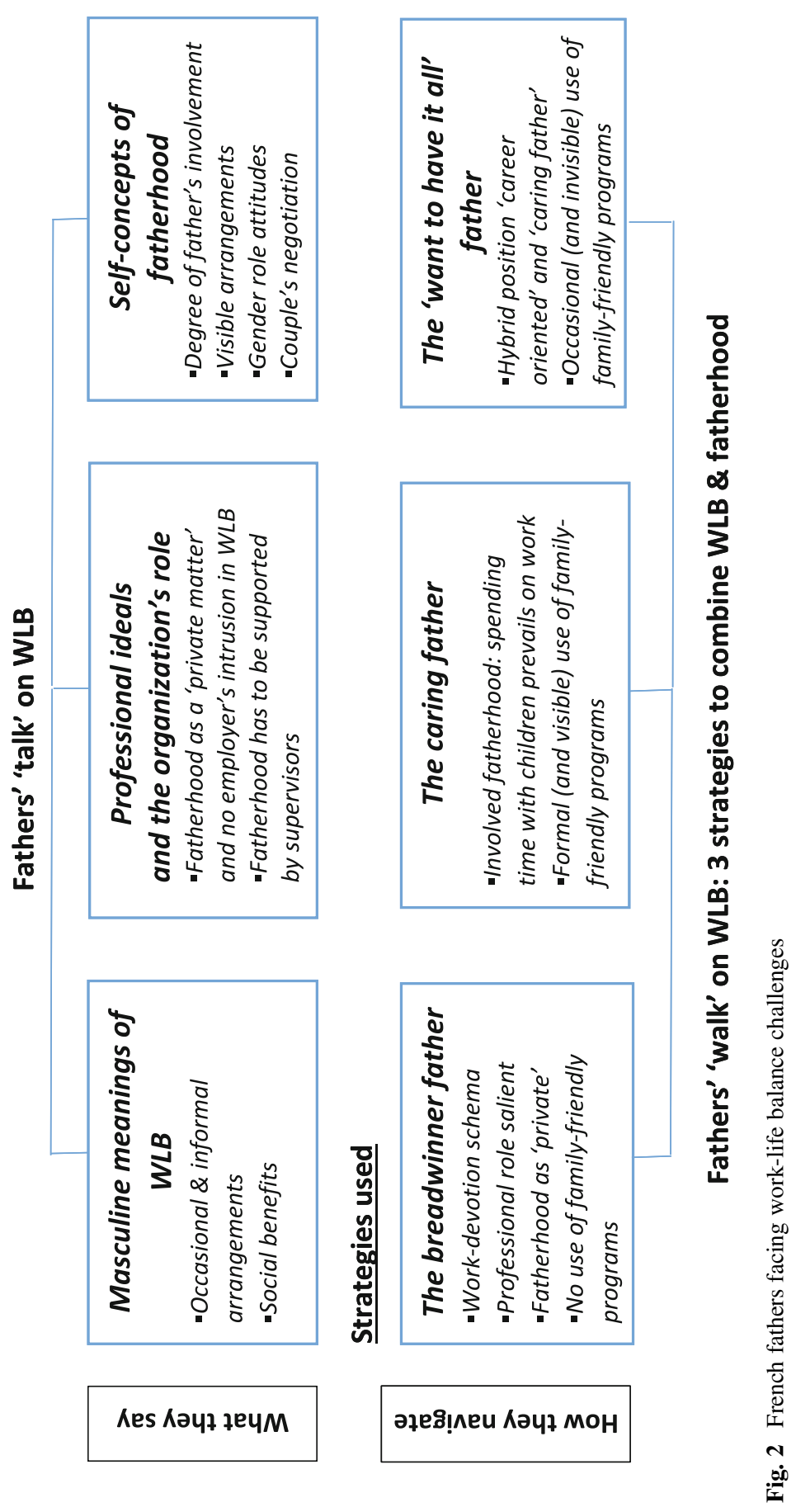


"I see that we might change more or less schedules when needed or take a day off [...] if I needed more flexibility than I have now, I would probably ask for it or maybe, before asking, I would look for a way... though I work as an analyst, I can do it here or at home. Therefore, before asking, I would probably think about a new work organization" [Yoann, 30, marketing analyst; married, 1 child].

\section{Discussion and Practical Recommendations}

The results highlight a masculine construction of what means WLB and provide evidence that men increasingly seek a better balance between their professional and family lives, but have their own representations of what WLB covers for them. Fathers in our study have specific conceptions of what WLB means because their needs are specific, and they generally do not feel identified with the current WLB initiatives, viewed as basically geared towards women (Lewis and Stumbitz 2017).

The findings show that while fathers expect an increasing adaptability, support, and flexibility from their organizations, they also have to deal with challenging tensions related to their professional aspirations and the visibility of their fatherhood practice. Research indicates the existence of barriers (Coltrane et al. 2013; Possinger 2017; Tanquerel and Grau-Grau 2020) to men taking up WLB measures due to strong dominant norms of masculinity constructed as breadwinner not as caregiver. Organizational expectations on working time interact with gendered norms about the ideal worker and the ideal caregiver (Gregory and Milner 2011). Our findings support this view showing that fathers' cultural patterns of masculinity and fatherhood remain strongly linked to work. Working and leading a successful career are still part of contemporaneous masculine identity (Neumann and Meuser 2017).

Our results also show that fathers' expectations regarding the role the organization has to play in WLB facilitation are not homogeneous, some of them claiming an active organizational support and others rejecting the employer's interference. In that sense, class may be an important element in determining men's strategies to balance work and non-work spheres, as professional men are better able to take advantage of flexible work arrangements and organize their working schedules, passing as 'ideal workers' (Reid 2015), while working-class men more often use shift work to balance work and family demands (Kaufman 2013). As some studies argued (Williams 2010), as men occupy higher job positions, they also have more autonomy and ask for less formal flexibility. This research tends to show that the fathers in lower positions need more help and support from the organization and supervisor while fathers in managerial positions do not express this need. Men continue to negotiate and position themselves in relation to hegemonic masculinity as a taken for granted set of norms (Hunter et al. 2017). The degree of compliance with this set of norms determine which visible or invisible strategies fathers decide to leverage. 


\subsection{Practical Recommendations}

Organizational policies must take account of men's positioning regarding traditional versus non-traditional masculinity and their heightened sensitivity to organizational norms (Harrington et al. 2015). Most men are so organization-centric that the organization has to provide them with more legitimacy (Kaplan et al. 2017). To do so, policies must tackle both societal expectations of men's roles (McDonald and Jeanes 2012) as well as implicit gender-coding of norms and policies to increase the feeling that men have the possibility to supportive measures (Hobson 2014).

A free choice approach would agree that if more men desire more time and if policies, which support mothers at work, are in place, men would access them. Yet, organizations tend to construct such policies in gender-neutral terms, which do not necessarily recognize structural or cultural barriers for their usage, and which tend to reinforce existing socio-economic inequalities (Williams 2010). Many fathers are somehow not fully enabled by their organizations to use policies (Moran and Koslowski 2019). Including men in the 'work-life' debate cannot simply be a matter of applying the same policies as those designed to help women to negotiate paid employment and motherhood. It is not enough. There is a need to challenge gendered ideal worker assumptions and traditional views of masculinity and fatherhood. As Harrington suggests in his chapter of this volume, employers should go further to help fathers be more engaged caregivers: "having a father's employee network that provides dads the opportunity to discuss their concerns and needs regarding caregiving and balancing their work-family demands; offering flexible work options that support dads as they strive to meet both their professional and personal responsibilities; establishing a voluntary mentoring program for fathers interested in not just career-related dialogue but which also includes conversations regarding the work-family dilemmas and challenges men face...."

In a general way, challenging deeply held convictions about women and men and their reproductive and economic roles in wider society would potentially involve support from a range of key stakeholders, including government, employers, and educational organizations. Research shows several measures to counter such barriers and to focus on targeted measures for men, which increase their visibility in the workplace (Burnett et al. 2013) and therefore create a sense of entitlement. Changes can also come from championing by male role models. Redefining fathers' roles from a societal (national fatherhood regimes), organizational (supportive work environment), and individual perspective (new masculinity) - is necessary to change the hegemonic gender order. Future research could focus on whether or not changes in masculinity are merely cosmetic or whether they actually contribute to shifting gender norms' (Hunter et al. 2017).

The empirical work presented in this chapter, although exploratory, makes a significant contribution to our understanding of WLB policy and practice, particularly as it relates to French fathers. This research demonstrates that a shift in employer approaches to support fathers who seek access to family-friendly policies 
is necessary (Stovell et al. 2017). Organizations should accompany men in their changing roles and consider their WLB requests as legitimate as for women.

Acknowledgements The author thanks Harvard Kennedy School's Women and Public Policy Program (WAPPP), the Social Trends Institute (STI) and the International Center for Work and Family for initiating, funding and supporting the conference 'Elevating Fatherhood: Policies, Organizations and Health \& Wellbeing'. She also thanks all the participants of the conference for their enlightened suggestions and helpful comments to improve this chapter. She finally thanks all the fathers who kindly accepted to share their experience in this research.

\section{References}

Blair-Loy M (2003) Competing devotions: career and family among women executives. Harvard University Press, Cambridge

Blossfeld H-P, Mills M, Bernardi F (2006) Globalization, uncertainty and Men's careers: an international comparison. Edward Elgar, London

Brandth B, Kvande E (2002) Reflexive fathers: negotiating parental leave and working life. Gender, Work \& Organization 9(2): 186-203

Brugeilles C, Sebille P (2009a) La Participation des Pères Aux Soins et à L'éducation des Enfants. L'influence des Rapports Sociaux de Sexe Entre les Parents et Entre les Générations. Politiques Sociales et Familiales 95:19-32

Brugeilles C, Sebille P (2009b) Pères et Mères Face aux Activités Parentales: Un Partage Inégalitaire. in Régnier-Loilier A. (dir.), Portraits de Familles. L'enquête Étude des Relations Familiales et Intergénérationnelles, Ined, coll. "Grandes enquêtes », : 241-264

Brugeilles C, Sebille P (2011) Partage des Activités Parentales: Les Inégalités Perdurent. Revue des Poliques Socialesti et Familiales 103:17-32

Brugeilles C, Sebille P (2013) Le Partage des Tâches Parentales: Les Pères, Acteurs Secondaires. Informations Sociales 2(176):24-30

Budig MJ, England P (2001) The wage penalty for motherhood. Am Sociol Rev 66(2):204-225

Burnett SB, Gatrell CJ, Cooper CL, Sparrow P (2013) Fathers at work: a ghost in the organizational machine. Gender, Work \& Organization 20(6):632-646

Cain Miller C (2014) Being a father is good for your career, but don't get carried away. The Upshot, New York Times. https://www.nytimes.com/2014/11/14/upshot/being-a-father-is-good-foryour-career-but-dont-get-carried-away.html

Carrigan T, Connell B, Lee J (1985) Toward a new sociology of masculinity. Theory Soc 14 (5):551-604

Castelain-Meunier C (2005) Les Métamorphoses du Masculin. Presses Universitaires de France, Paris

Castelain-Meunier C (2013) Le Ménage: La Fée, la Sorcière et L'homme Nouveau. Stock, Paris

Collinson D, Hearn J (1994) Naming men as men: implications for work, organization and management. Gend Work Organ 1(1):2-22

Collinson D, Hearn J (2005) Men and masculinities in work, organizations, and management. In: Kimmel M, Hearn J, Connell RW (eds) Handbook of studies on men and masculinities. Sage, Thousand Oaks, pp 289-310

Coltrane S, Miller EC, Dehaan T, Stewart L (2013) Fathers and the flexibility stigma. J Soc Issues 69(2):279-302

Connell RW (1995) Masculinities. Polity Press, Cambridge

Connell RW, Messerschmidt JW (2005) Hegemonic masculinity: rethinking the concept. Gend Soc 19(6):829-859 
Cooper M (2000) Being the 'go-to guy': fatherhood; masculinity; and the organization of work in Silicon Valley. Qual Sociol 23(4):379-405

Coser LA (1974) Greedy institutions: patterns of undivided commitment. Free Press, New York

Dermott E (2008) Intimate fatherhood: a sociological analysis. Routledge, London

Doucet A, Merla L (2007) Stay-at-home fathering: a strategy for balancing work and home in Canadian and Belgian families. Community Work Fam 10(4):455-473

DREES (2016) Le Congé de Paternité: Un Droit Exercé par Sept Pères sur Dix. Études et Résultats, $\mathrm{n}^{\circ}$ 957, Drees, Mars

DREES (2018) L'offre D'accueil Collectif des Enfants de Moins de Trois ans en 2015. Nadia Amrous et Françoise Borderies, Série « statistiques », n 203, janvier 2018

Elliott K (2016) Caring masculinities: theorizing an emerging concept. Men Masculinities 19 (3):240-259

Galinsky E, Aumann K, Bond JT (2009) Times are changing: gender and generation at work and at home. Families and Work Institute, New York

Gatrell CJ (2011) 'I'm a bad mum': pregnant Presenteeism and poor health at work. Soc Sci Med 72 (4):478-485

Gioia DA, Corley KG, Hamilton AL (2013) Seeking qualitative rigor in inductive research notes on the Gioia methodology. Organ Res Methods 16(1):15-31

Gomajee R, El-Khoury F, Van Der Waerden J, Pryor L, Melchiorthe M (2017) Early life childcare and later behavioral difficulties: a causal relationship? Data from the French EDEN study. J Econ Behav Organ 181:344-359

Gregory A, Milner S (2008) Fatherhood regimes and father involvement in France and the UK. Commun Work Family 11(1):61-84

Gregory A, Milner S (2011) Fathers and work-life balance in France and the UK: policy and practice. Int J Soc Policy 31(1-2):34-52

Gregory A, Milner S (2012) Men's work life choices: supporting fathers at work in France and Britain. In: McDonald P, Jeanes E (eds) Men, wage work and family. Routledge, London

Haas L, Hwang CP (2019) Policy is not enough - the influence of the gendered workplace on fathers' use of parental leave in Sweden. Community Work Fam 22(1):58-76

Harrington B, Van Deusen F, Fraone JS, Morelock J (2015) How millennials navigate their careers: young adult views on work, life and success. Boston College Center for Work \& Family, Chestnut Hill

Harrington B, Van Deusen F, Humberd B (2011) The new dad: caring, committed and conflicted. Boston College Center for Work and Family, Chestnut Hill

Hobson B (2014) Conclusion. In: Hobson B (ed) Worklife balance: the agency and capabilities gap. Oxford University Press, Oxford, pp 266-287

Hochschild A, Machung A (1989) The second shift: working parents and the revolution at home. Viking, New York

Hunter SC, Riggs DW, Augoustinos M (2017) Hegemonic masculinity vs. a caring masculinity: implications for understanding primary caregiving fathers. Soc Personality Psychol Compass 11 (3): 12307

INSEE (2010) Enquête Emploi du temps en 2010. https://www.insee.fr/fr/statistiques/2118074

Kaplan D, Rosenmann A, Shuhendler S (2017) What about nontraditional masculinities? Toward a quantitative model of therapeutic new masculinity ideology. Men Masculinities 20(4):393-426

Kaufman G (2013) Superdads: how fathers balance work and family in the 21st century. NYU Press, New York

Kimmel MS (2004) Masculinity as homophobia: fear, shame, and silence in the construction of gender identity. In: Rothenberg PD, Mayhew KS (eds) Race, class, and gender in the United States: an integrated study. Worth, New York, pp 81-93

Kugelberg C (2006) Constructing the deviant other: mothering and fathering at the workplace. Gender, Work \& Organization 13(2):152-173

Kvande E (2009) Work - life balance for fathers in globalized knowledge work. Some insights from the Norwegian context. Gender, Work \& Organization 16(1):58-72 
Kvande E (2012) Control in post-bureaucratic organizations-consequences for fathering practices. In: Oechsle M, Muller U, Hess S (eds) Fatherhood in late modernity: cultural images, social practices, structural frames. Verlag Barbara Budrich, Opladen, pp 233-248

Ladge J, Greenberg D (2019) Maternal optimism: forging a positive path through work and motherhood. Oxford University Press, New York

LaRossa R (1988) Fatherhood and social change. Fam Relat 37(4):451-457

Le Talec JY (2016) Des Men's Studies aux Masculinity Studies: Du Patriarcat à la Pluralité des Masculinités. SociologieS [En ligne], Dossiers, Sociétés en Mouvement, Sociologie en Changement, mis en ligne le 07 mars 2016, consulté le 10 avril 2018

Levy JD (2005) Redeploying the state: liberalization and social policy in France. In: Streeck W, Thelen K (eds) Beyond continuity. Institutional Change in Advanced Political Economies. Oxford University Press, Oxford

Lewis S, Stumbitz B (2017) Research on work and family: some issues and challenges. In: Liebig B, Oechsle M (eds) Fathers in work organizations, inequalities and capabilities, rationalities and politics. Verlag Barbara Budrich Publishers, Opladen, pp 227-244

Liebig B, Oechsle M (eds) (2017) Fathers in work organizations, inequalities and capabilities, rationalities and politics. Verlag Barbara Budrich Publishers, Opladen

Marsh K, Musson G (2008) Men at work and at home: managing emotion in telework. Gender, Work \& Organization 15(1):31-48

Martial A (2016) Des Pères «En Solitaire »? Ruptures Conjugales et Paternité Contemporaine Aix-en-Provence: Presses universitaires de Provence

McDonald P, Jeanes E (eds) (2012) Men, wage and family. Routledge, New York

Milner S, Gregory A (2015) Fathers, care and family policy in France: an unfinished revolution? Families, Relationships and Societies 4(2):197-208

Moran J, Koslowski A (2019) Making use of work-family balance entitlements: how to support fathers with combining employment and caregiving. Community Work Fam 22(1):111-128

Moss P (ed) (2013) International review of leave policies and research 2013. International Network on Leave Policies and Research, London

Murgia A, Poggio B (2013) Fathers' stories of resistance and hegemony in organizational cultures. Gender, Work \& Organization 20(4):413-424

Neumann B, Meuser M (2017) Changing fatherhood? The significance of parental leave for work organizations and couples. In: Liebig B, Oechsle M (eds) Fathers in work organizations, inequalities and capabilities, rationalities and politics. Verlag Barbara Budrich publishers, Opladen, pp 83-102

OPE (2017) Baromètre 2017 de la Conciliation entre Vie pro et Vie perso (volet « Salariés »)

ORSE (2010) Livre 'Patrons papas, paroles de 10 dirigeants sur l'équilibre travail et vie privée'

ORSE (2014) Rapport 'Les hommes, sujets et acteurs de l'Egalité professionnelle'

Pailhe A, Solaz A (2009) Entre Famille et Travail. Des Arrangements de Couples aux Pratiques des Employeurs. La Découverte, Paris

Pak M, Zilberman S (2013) La Durée du Travail des Salariés à Temps Complet. DARES Analyses, no.047. https://dares.travail-emploi.gouv.fr/IMG/pdf/2013-047.pdf

Pocock B (2005) Work/care regimes: institutions, culture and behaviour and the Australian case. Gender, Work \& Organization 12(1):32-49

Possinger J (2017) The 'Daddy Months' in the German fatherhood regime: a step towards an equal share of work and care? In: Liebig B, Oechsle M (eds) Fathers in work organizations, inequalities and capabilities, rationalities and politics. Verlag Barbara Budrich publishers, Opladen, pp 185-204

Reid E (2015) Embracing, passing, revealing, and the ideal worker image: how people navigate expected and experienced professional identities. Organ Sci 26(4):997-1017

SPSS (2013) Projet de Loi des Finances de la Sécurité Sociale. Partie I: Données de cadrage, Paris: SPSS. http://www.assemblee-nationale.fr/14/projets/p10235.asp 
Stovell C, Collinson D, Gatrell C, Radcliffe L (2017) Rethinking work-life balance and wellbeing. The perspectives of fathers. In: Cooper CL, Leiter MP (eds) The Routledge companion to wellbeing at work. Routledge, London

Tanquerel S, Grau-Grau GM (2020) Unmasking work-family balance barriers and strategies among working fathers in the workplace. Organization 27(5):668-700

UNAF (2016) Réseau national des Observatoires des Familles, 2016. Note de synthèse n ${ }^{\circ} 8$ «Etre père aujourd'hui ! »16/06/2016 https://www.unaf.fr/IMG/pdf/bro_20p_obsv_familles_8finale_2_.pdf. Etude n ${ }^{\circ} 8$ de l'Observatoire des familles menée par 42 UDAF et 2 URAF en 2015 dans 48 départements auprès d'une sélection de 3000 ménages allocataires de CAF ayant au moins un enfant à charge âgé de 4 à 20 ans

Williams JC (2010) Reshaping the work-family debate: why men and class matter. Harvard University Press, Cambridge

Wood G, Newton J (2006) Childlessness and women managers: 'choice', context and discourses. Gender, Work \& Organization 13(4):338-358

Yancey Martin P (2001) 'Mobilizing masculinities': Women's experiences of men at work. Organization 8(4):587-618

Open Access This chapter is licensed under the terms of the Creative Commons Attribution 4.0 International License (http://creativecommons.org/licenses/by/4.0/), which permits use, sharing, adaptation, distribution and reproduction in any medium or format, as long as you give appropriate credit to the original author(s) and the source, provide a link to the Creative Commons license and indicate if changes were made.

The images or other third party material in this chapter are included in the chapter's Creative Commons license, unless indicated otherwise in a credit line to the material. If material is not included in the chapter's Creative Commons license and your intended use is not permitted by statutory regulation or exceeds the permitted use, you will need to obtain permission directly from the copyright holder. 